Institute of $\mathbf{F}_{\text {ood and }} \mathbf{A}_{\text {gricultural }} \mathbf{S}_{\text {ciences }}$

\title{
Amendments at Planting and Backfilling 1
}

\section{Edward F. Gilman, $\mathrm{PhD}^{2}$}

Straps, ties, burlap and string are sometimes left tightly secured around the root ball after planting. This is not recommended. Some people are under the mistaken impression that synthetic string and wire will decompose with time. This is usually not the case. They can girdle the trunk as it grows and could kill the tree if left on. Cut and remove all straps, burlap, wires and string from around the trunk and top of the root ball before filling soil in around the root ball. Remove all synthetic burlap from the root ball since it can restrict root enlargement. Natural treated or untreated burlap can be left on the sides of the ball because it typically decomposes quickly in regions receiving more than 30 " annual rainfall.

Loosen and break up large clods of soil before backfilling. Clods of soil used as backfill create air pockets around the ball and could hinder root growth and establishment. After filling the bottom half of the space around the root ball with backfill soil and tamping lightly with a shovel, push a hose with running water in and out of the backfill soil all around the hole. Washing the backfill will settle the soil around the root ball and eliminate air pockets. It may not be necessary if the planting hole is at least twice the width of the root ball because a shovel can be sliced through the backfill to eliminate air pockets. Add soil so that it is even with the top of the landscape soil. Do not cover the root ball with soil.
Only a thin layer of mulch (1") should be placed on top of the root ball.

In all but exceptional circumstances where the soil is very poor, extensive research on trees clearly shows that there is no need to incorporate any amendments, fertilizers, living organisms, spores, dusts, powders, gels, humic acids, organic products, etc. into the backfill soil. It is better to replace bad soil than to attempt to amend it.

Simply use the loosened soil that came out of the planting hole. The exception to this rule is where existing soil is so terrible or contaminated, such as in a parking lot island or in a small cutout in a sidewalk, that all soil over a large area is replaced with good-quality soil. In addition, there have been huge growth responses to applications of spores of mycorrhizae-forming fungi in strip mine soils because many are essentially sterile. This is a good practice and is often recommended. However, there are few, if any, reports of a response in urban and suburban landscapes. In fact, most studies to date clearly show no response.

Research on tiny seedlings showed that addition of the growth regulator paclobutrazol to the root ball at the appropriate rate at transplanting could increase the root:shoot ratio and might reduce water stress

1. This document is ENH871, one of a series of the Environmental Horticulture Department, Florida Cooperative Extension Service, Institute of Food and Agricultural Sciences, University of Florida. Original publication date July 12, 2002. Visit the EDIS Web Site at http://edis.ifas.ufl.edu.

2. Edward F. Gilman PhD, Professor, Environmental Horticulture, University of Florida, Gainesville, FL 32611

The Institute of Food and Agricultural Sciences is an equal opportunity/affirmative action employer authorized to provide research, educational information and other services only to individuals and institutions that function without regard to race, color, sex, age, handicap, or national origin. For information on obtaining other extension publications, contact your county Cooperative Extension Service office. Florida Cooperative Extension Service/Institute of Food and Agricultural Sciences/University of Florida/Christine Taylor Waddill, Dean. 
(Watson, 2001). More work is needed on this before it can be recommended.

Slow-release (or controlled-release) fertilizer can be applied on top of the root ball and backfill soil or on top of the mulch at planting. There is no need to mix it with the backfill soil or place it at the bottom of the planting hole since most roots end up close to the soil surface in urban and suburban landscapes. Fertilizer will leach with rain and irrigation to reach the roots. Under most circumstances, mulch will not steal the fertilizer from the tree.

Adding slow-release fertilizer at planting has not been associated with either improved survival or increased growth after planting in fairly good soil. There is little fertilizer research in poor soils, but more than a few horticulturists think plants may benefit from application at or soon after planting. It will not hurt the plant provided it is applied according to the directions on the product. On the other hand, adding soluble fertilizer to a newly installed plant could burn roots. This will injure the plant and could kill it. In short, fertilizer is not usually needed at planting.

\section{More Information}

More information about planting trees can be found at http://hort.ifas.ufl.edu/woody/planting 